University of Massachusetts Amherst ScholarWorks@UMass Amherst

Anthropology Department Faculty Publication

Series

Anthropology

July 2009

\title{
Environmental Justice and Roma Communities in Central and Eastern Europe
}

Krista Harper

University of Massachusetts - Amherst, kharper@anthro.umass.edu

Tamara Steger

Central European University

Richard Filcak

Institute of Forecasting, Slovak Academy of Sciences

Follow this and additional works at: https://scholarworks.umass.edu/anthro_faculty_pubs

Part of the Anthropology Commons, Environmental Policy Commons, Public Policy Commons, Social Policy Commons, and the Urban Studies and Planning Commons

\section{Recommended Citation}

Harper, Krista; Steger, Tamara; and Filcak, Richard, "Environmental Justice and Roma Communities in Central and Eastern Europe" (2009). Environmental Policy and Governance. 5.

https://scholarworks.umass.edu/anthro_faculty_pubs/5 


\title{
Environmental Justice and Roma Communities in Central and Eastern Europe
}

by Krista Harper, $\mathrm{PhD}$

Department of Anthropology and the Center for Public Policy and Administration, University of Massachusetts Amherst, USA

(Correspondence: Prof. Harper, Department of Anthropology, 214 Machmer Hall, University of Massachusetts, Amherst, MA 01002 USA or $<$ kharper@anthro.umass.edu $>$ )

Tamara Steger, PhD

Department of Environmental Sciences and Policy, Central European University, Budapest, Hungary

and Richard Filčák, PhD

Institute for Forecasting, Slovak Academy of Sciences, Bratislava, Slovak Republic

\begin{abstract}
:
Environmental injustice and the social exclusion of Roma communities in Central and Eastern Europe (CEE) has roots in historical patterns of ethnic exclusion and widening socioeconomic inequalities following the collapse of state socialism and the transition to multi-party parliamentary governments in 1989. In this article, we discuss some of the methodological considerations in environmental justice research, engage theoretical perspectives on environmental inequalities and social exclusion, discuss the dynamics of discrimination and environmental protection regarding the Roma in CEE, and summarize two case studies on environmental justice in Slovakia and Hungary. We argue that when some landscapes and social groups are perceived as "beyond the pale" of environmental regulation, public participation, and civil rights, it creates local sites for externalizing environmental harms.
\end{abstract}

KEYWORDS: environmental justice, environmental inequalities, Roma (Gypsies), Central and Eastern Europe, Hungary, Slovak Republic.

PRE-REVIEW VERSION: This is the pre-peer-reviewed version of the following article: Harper, Krista, Tamara Steger, and Richard Filcak. 2009. Environmental Justice and Roma Communities in Central and Eastern Europe. Environmental Policy and Governance 19:4 (July/August 2009), which will be published in revised final form at http://www3.interscience.wiley.com/journal/121640454/grouphome/home.html 


\section{INTRODUCTION:}

When the contemporary environmental movements of the global North emerged in the 1960s and 1970s, it was an unprecedented call for a better quality of life. A growing number of citizens called for policymakers to value more closely clean air, water, soil, and biodiversity. Environmentalists asked citizens of the global North to reduce consumerism-the main driver of industrial growth--and to embrace a healthier environment by minimizing pollution, reducing waste, and conserving natural resources. Many environmentalists believed that the achievement of these goals would ensure a better quality of life for everyone. Eventually, however, the movement was faced with a dilemma. While much of the environmental movement assumed a universal need for a healthy environment, the opportunity to define and assert this fundamental need were not universal. Those with the least social, economic, and political capacity were likely to receive fewer environmental benefits while enduring more of the harms. This dilemma gave rise to popular movements demanding environmental justice.

Scholars and activists around the world began to articulate and address the need for justice in the distributive and procedural aspects of environmental harms and benefits. This culminated in environmental justice movements around the globe with substantive claims backed by research (United Church of Christ, 1987; Bowen and Wells, 2002; FOE, 2001; Harper and Rajan, 2007; Raina, 2000; Taylor, 2000). Supported largely by ethnic minorities and poor people, environmental justice initiatives widened the window of participation in the call for a better quality of life through a healthier environment. These movements, however, were not only about fair treatment when it comes to the environment, but also social inclusion, participation in decision-making, and recognition (Schlosberg, 2004).

In the last several years, advocacy for environmental justice took root in Central and Eastern Europe (CEE). ${ }^{1}$ Research on environmental justice in CEE also grew, and confirmed that indeed discrimination plays a role in the distribution of environmental harms and benefits, particularly in the case of the Roma (Filčák, 2007, Steger et al., 2007). This research supports the observation that in certain locations, members of ethnic minorities, communities of lower socioeconomic status, and the least educated disproportionately: 1)

1 See www.cepl.ceu.hu. 
suffer from exposure to environmental hazards due to their proximity to hazardous waste sites, incinerators, factories, abandoned industrial facilities and other sources of pollution; and/or 2) are denied environmental benefits such as potable water, sewage treatment facilities, sanitation, and access to natural resources; and/or 3) witness the conceptualization of their living space as "beyond the pale" areas where environmentally controversial practices are concentrated. While environmental justice has to do with overcoming unfair distribution and procedural practices regarding environmental harms and benefits in general, we have found that the situation and experience of Roma ethnic minorities not only affirm new theories that expand the notion of environmental justice beyond the United States (US) conceptualization, but also contribute to further understanding of the "environmentalism of the poor" (Martinez-Alier, 2002).

In this article, we explore some methodological considerations in order to nurture the debate on the study of environmental justice and summarize the relevant theoretical perspectives on environmental justice and social exclusion. We provide an overview of some of the general research findings on environmental justice in CEE including the dynamic forces that create, maintain, or intensify injustices, highlighting two case studies in Slovakia and Hungary. In conclusion, we draw upon the case study examples to gain comparative insights in light of our theoretical framework.

\section{METHODOLOGIES FOR STUDYING ENVIRONMENTAL JUSTICE ISSUES}

The study of environmental justice is an area that has had increasing attention amongst scholars who seek both to understand and make claims about environmental injustices as well as maintain or strengthen the scientific approaches that lead to such understanding and increase the validity of claims (Baden et al., 2007; Downey, 2007). Research on environmental justice can have especially practical or meaningful implications when: 1) the dynamic forces that generate, maintain, or change the unjust situation are explored; 2) integrated or complementary approaches are considered; and 3) communitylevel, participatory research is engaged.

There is significant research on environmental justice that maps environmental inequities (Ash and Fetter, 2004; Pastor, et al., 2005). While this research has not only played a significant role in drawing attention to environmental justice and inspired 
movements for environmental justice, it is insufficient in terms of guiding scholars and activists on how to address the underlying forces that bring about and sustain injustices. While there may be a correlation between higher pollution levels and lower incomes in certain communities, it may or may not mean that a particular industry emits more pollution because the surrounding community is poor (Gouldson, 2006). In addition to the mapping of static inequities, more attention needs to be given to identifying the dynamics that give rise to or maintain inequity (Baden et al., 2007; Bowen and Haynes, 2000). The section on "Environmental Injustice in CEE: Dynamics and Details" provides a contextual understanding of the forces that are related to the political ecology of Roma communities in CEE.

Mapping the distribution of environmental harms and benefits across demographies is not simple, and every research approach has strengths and weaknesses. In the end, we argue for varied and integrative approaches and provide an example in Filčák’s research in Central and Eastern Europe that demonstrates such an integrated approach (see the section, "Case Study: Slovakia"). Filčák's project brings together the generalizability of survey and rapid rural assessment approaches with the rich detail that can be garnered from a fine-grained, qualitative lens. An integrated approach captures the strengths while overcoming the weaknesses associated with strictly large-N or small-N case research (Ragin, 2000).

Scholarly contributions to the literature on environmental justice have engaged a lively debate on both the spatial scale and the scope of analysis. We specifically draw your attention to the importance of community-based approaches for several reasons. The role and level of discrimination is acutely assessed at the community level. Downey concludes, for example, that degrees of environmental racial inequalities in the US vary depending on location (2007). More community oriented research can facilitate environmental justice mobilizations as well as unveil differences in risk perception (Briggs, 2006; Delamos, 2006; Norgaard, 2007). Neighborhood comparisons in a single city can furthermore be critical to shedding light on environmental injustices (Kingham et al., 2007). In the Hungarian case study presented in this article, a small Roma community engages in a participatory action research initiative that is rich in generating understandings and agency, while pointing to the limitations of civil sphere organizations (see the section, "Case Study: Sajószentpéter, Hungary"). Combining PAR approaches with a comparative research framework allows 
scholars to recognize broader patterns at work in a specific setting and to build policy analysis that can be applied beyond the immediate local context. Before venturing into this empirical world, we present theoretical assumptions that provide an emerging framework for reflecting on environmental justice in CEE.

\section{THEORETICAL APPROACHES TO ENVIRONMENTAL JUSTICE IN CEE}

Until recently, many scholars studying the environmental movement in North America and Europe conceived of environmentalism as a "post-materialist" movement supported largely by young, white, middle-class citizens (Inglehart 1977). This, in turn, mistakenly nurtured a common sense perception among some that low-income and socially excluded groups care less about the environment than their middle-class, majority counterparts (Heinz, 2005, De la Pena, 1990). More recently, environmental scholars Doherty and Doyle identified three major frames in transnational environmentalism: postcolonial, post-materialist, and post-industrial environmentalisms (2006). Post-materialist environmentalism has provided a dominant framework for large nature conservation organizations based in the global North. Post-colonial environmentalism, in contrast, represents struggles for sustainable livelihood (particularly in the global South) while postindustrial environmentalism applies a political ecology analysis of social and environmental inequalities. Environmental economist Martinez-Alier points to the "environmentalism of the poor" as an emerging field of mobilization, combining elements of post-colonial and post-industrial environmentalism to address the unjust displacement of ecological "sources and sinks," the preservation of traditional ecological knowledge, and the struggle for environmental justice (Martínez-Alier 2002). We find aspects of both post-colonial and post-industrialist environmental critique pertinent to environmental injustices in CEE.

Race and ethnicity can be important aspects in understanding popular environmentalism, but they may not be central in every setting where environmental injustices are present. Martínez-Alier cautions against applying the "environmental racism" framework to all environmental injustices on a global scale:

The language of 'environmental racism' is powerful, and it can be used in many cases of environmental injustice, but not all. For instance, the Narmada struggle [against the construction of a large-scale dam system in India] is not being fought in 
terms of “environmental racism.” (Martínez-Alier 2002: 172)

Nevertheless, Martínez-Alier acknowledges that the confluence of environmental activism and lessons learned from the US civil rights struggle has fundamentally shifted the discourse on environmental harms toward a more intrinsic or inherent valuation of humans and nature and points to previously untapped possibilities for integration, "where anti-racism and environmentalism are now walking together" (Martínez-Alier, 2002: 182). Juanita Sundberg, in her analysis of the role of race in environmental justice in Latin America, argues that "tracing how racial processes work through environmental formations will help to understand not only how exclusionary discourses and practices work, but also how they come to appear justifiable and indeed necessary" (Sundberg, 2004 and 2007). Following Ladányi and Szelényi's analysis of post-socialist patterns of social exclusion (2006), we argue that in the case of Roma in CEE, spaces inhabited by low-income Roma have come to be "racialized" during the post-socialist era, intensifying patterns of environmental exclusion along ethnic lines.

Martínez-Alier's observes that "ecological distributional conflicts are fought with different vocabularies" (Martínez-Alier, 2002: 172). Struggles over environmental injustices in different settings draw from a variety of cultural frames and repertoires of political agenda building, advocacy or action. Environmental justice advocacy in the US drew extensively from the vocabulary of the civil rights movement and was closely linked to bottom-up, community-based activism. Cole and Foster (2000) describe how environmental justice struggles in the US are often led by people, often women, with no political organizing or activist experience, especially in neighborhood struggles over toxics risks. In contrast to the US situation, cases of community struggles for equal treatment in the distribution of environmental harms in the United Kingdom (UK) are led by professional environmental organizations with a highly educated staff and international expertise (e.g., Friends of the Earth), as well as by grassroots ethnic minority organizations (Agyeman, 2002). These campaigns have focused on the effects of "Pollution Injustice" on low-income communities and on ethnic minorities' access to the countryside and green space. Approaches developed in the UK provide inspiration for how we might look at forms of unequal exposure to harm or access to environmental benefits that go beyond the anti-toxics initiatives. The experiences from the US and the UK illustrate commonalities, but also 
different ways of constructing environmental justice and point to the importance of local conditions and vocabularies in analyzing the forms and scope of unequal treatment.

These possibilities could be expressed in CEE through the integration of environmental protection and social inclusion. To date, attempts at such policy integration or activist alliances have been rare; post-socialist policies addressing the conditions of Roma communities have been framed through an ethnic lens as "Roma issues," resulting in an ethnicized policy silo (Kovats, 2003; Trehan and Koczé, n.d.; Vermeersch, 2007). For mobilizations to be effective, activists in CEE must develop a vocabulary for addressing environmental injustices that is analytically applicable and strategically effective in the context of the European Union and especially at the local and national level in its newest member states. Such "vocabularies" are fundamental in the struggle for recognition that is so characteristic of environmental justice movements around the globe (Schlosberg, 2004).

One reason we have seen little overlap between environmental and social inclusion concerns is the fact that poor and minority communities have often been portrayed as indifferent to environmental issues (Mohai, 1990; Taylor, 2000). This social construction of the environment and "environmental subjects" or identities has practical, concrete effects. In the context of research on environmental justice movements in the United States, scholars have examined how activists have negotiated the politics of identity in multiethnic coalitions (Checker, 2001) and how ethnic identities may produce new kinds of environmentalist identity (Pulido, 1996). Scholars working on environmental politics in the global South have written extensively on the politics of indigenous people's identities (or "indigeneity") in relation to the environment (Brosius, 1997; Li, 2004). Arun Agrawal, studying a region where local villagers once set fire to colonial forest preserves, examines the production of new environmental identities through community participation in forest management (Agrawal, 2005). As we shall present in the next section, Roma in CEE are rarely perceived as "environmental subjects" by themselves or others although struggles for access to housing and public infrastructure have played a critical role in grassroots organizing in many Roma communities.

\section{ENVIRONMENTAL INJUSTICE IN CEE: DYNAMICS AND DETAILS}

Political Changes and Transition: The debate on the causes of environmental problems and the distribution of adverse effects of industrial production in Central and 
Eastern Europe (CEE) has been delayed and simplified in comparison to other more developed countries. This is mainly due to the political oppression prior to the political changes of 1989 and limited access to literature, information and contacts from outside the state socialist sphere. The official party line under the former socialist regimes was that socioeconomic inequalities no longer existed and that conditions and opportunities were absolutely equal for all. In fact, in many countries throughout the region, the well-being of Roma rose as they were included as workers in the socialist industrial system (Kovats 2003). Social stratification and marginalized groups nevertheless existed.

Prior to 1989, all of the state socialist governments of CEE officially stated their commitment to environmental protection and established national parks and nature preserves beginning in the 1970s. In most cases, however, the party leadership gave priority to industrial development. Industrial priority was very similar to the policies of capitalist countries, but in the West by the 1960s and 1970s, a new emphasis on environmental protection and pollution began to emerge. In the centralized economies of CEE, this new path of development was not immediately pursued for several reasons. Public participation was discouraged, and so environmental movements developed slowly. Other reasons included a development framework of self-sufficiency that limited opportunities to transfer problematic production to other countries and structural barriers to a transition from industrial production to a service-economy.

In the late 1980 s and early 1990s, public concern regarding the environmental impacts of industrial projects, such as dam construction and mining, grew (Harper 2005; Tickle and Welsh 1998; Pickvance 1998; Steger, 2008). Policymakers under the newly established regimes responded to this growing concern for environmental protection, but believed that environmental protection could be achieved alongside marketization through the democratization of political decision-making practices (Reilly 1989; Costi 2003) and the institutionalization of environmental protection. Post-1989 policymakers thus addressed a new array of environmental issues, but generally gave priority to privatization and economic development (Baker and Baumgartl, 1994; Dominick, 1998). Meanwhile, restructuring the economy, which was gradually done in the developed countries, took a rapid and to some extent chaotic path.

The early 1990s black-and-white portrayal of the free market system as a tool for 
solving all environmental (economic and social) problems has gradually been followed by disillusionment with the environmental and the social impacts of economic development (Gille 2007). While the environmental situation in CEE improved during the early stages of transition -- attributed in part to the decline in industrial production, and new environmental legislation motivated by the process of accession to the European Union (EU) -- industrial production and the subsequent environmental impacts are on the rise once again (Barnes and Barnes, 1999; McCormick, 2001). Economic hardships in post-socialist countries and subregions heavily pressure policymakers to allow (or support) projects based on a large-scale exploitation of natural resources or projects with adverse environmental impacts on the environment.

The transition to a free market economy in CEE countries has led to further impoverishment of groups and individuals with low adaptability to the new conditions (World Bank, 2000; Emigh et al., 2001). People in rural areas and workers with less education and marketable skills have suffered the most in the transformation (UNDP, 2002; World Bank, 2003). The newfound capacity to organize civil society organizations has not been able to compensate for the devastating effects of mass unemployment (Kovats, 2003). In addition to poverty, these groups are also particularly vulnerable when it comes to the adverse impacts of industrial development. These new circumstances have proven to be especially troubling in the case of the Roma of CEE, an ethnic minority experiencing a long history of discrimination and disproportionate levels of poverty throughout Europe.

With accession to the European Union (EU), CEE countries have had to make institutional and legal adjustments to meet EU standards. For example, much of the introduction of stronger environmental legislation in CEE countries is driven by EU accession and membership. The EU provides an emerging framework for the promotion of environmental protection, human rights, and health (Steger and Filčák, 2008). For example, in the Charter of Fundamental Rights of the European Union and European Union Sustainable Development Strategy (EU SDS), the EU has additionally drawn attention to the importance of social cohesion. Serious EU efforts in these realms, however, will require an elaborated regulatory framework that specifically targets environmental justice (Antypas et al., 2008). Furthermore, asserting a framework for such important measures does not always guarantee implementation, which can be challenging for new member states due to 
various constraints, including economic and administrative barriers.

Still, one could feasibly argue that civic-based initiatives calling for environmental justice in Europe are definitively underway. The Environmental Justice Program at the Central European University, Center for Environmental Policy and Law convened environmental and human rights organizations from $\mathrm{CEE}$ and the US to promote environmental justice in Europe and across the globe (see www.cepl.ceu.hu/ejp). Several local, collaborative efforts between environmental and human rights organizations (particularly those focusing on Roma issues) have been inspired by this transatlantic initiative to address environmental injustices in CEE (Pellow et al., 2005). Friends of the Earth in collaboration with the Economic and Social Research Council and the London School of Hygiene and Tropical Medicine have also worked to strengthen environmental justice in Europe (ESRC, 2001). The Health and Environment Alliance (HEAL) in Brussels supported research to explore the health implications of environmental injustices, and lobbies at the EU level to specifically consider environmental justice issues in the promotion of environmental protection and health. Housing rights violations are increasingly articulated as environmental injustices and environmental laws are being applied to mutually address environmental problems and social injustices.

\section{Social Construction of the Roma}

Majority groups in Europe have alternately romanticized Roma as carefree, creative spirits or denigrated them as profligates and social parasites (Hancock, 2002; Lemon, 2000). These twin stereotypes contributed to the marginalization of Roma in feudal and capitalist peasant economies, in the state socialist collective economy, and in the post-socialist, deindustrializing economy. The transformation from state socialism caused a decrease in mining, heavy industries, and agricultural production, and new technologies have reduced the demand for unskilled workers. Roma, who left traditional trades during the socialist era to work as miners, woodcutters, unskilled factory workers, and seasonal workers on cooperative farms, are no longer included in the labor force. Post-socialist economic reorganization has deeply affected non-Roma inhabitants of villages. As the Roma were among the first who lost their jobs, the non-Roma focused on protecting the remaining opportunities. Since Roma are no longer needed for the villages' economies, from the perspective of the majority, there is no reason to have them in the village. In some cases, 
this has led to a phenomenon of "white flight" from villages and the creation of "rural ghettos"- once multi-ethnic villages now populated solely by the poorest Roma (Ladányi and Szelényi, 2006).

At the present time, Roma are not recognized and for the most part do not see themselves as environmental subjects. Nevertheless, struggles over access to housing and public infrastructure and vulnerability to floods were key issues in early Roma civil rights mobilizations in Hungary (Ladányi, 1991). As Agrawal's work demonstrates, environmental identity is malleable and can emerge in a relatively short period of time. Increased Romani participation in environmental projects and decision-making may result in the development of new environmental identities, but these identities will have to contend with pre-existing stereotypes of Roma.

Contemporary environmental discourses tend to portray marginalized and indigenous people in either of two ways: as noble savages or as environmental profligates (Krech, 1999). Unlike indigenous people, however, the Roma in Hungary are not associated with a timeless, revered "environmental ethic"-perhaps because they were excluded from owning land (Csalog, 1994). In fact, the most destitute Roma have been chided for their short-sighted use of environmental resources: heating the house with forest wood and parts of the house itself (Ladányi and Szelényi, 2006; Autonomia/UNDP, 2004), engaging in extremely hazardous scrap metal processing, and allegedly overharvesting snowdrop flowers to sell in the city. While many observers acknowledge the structural inequalities and histories underlying Roma communities' rural and post-industrial indigence, the fact remains that non-Roma widely see the Roma as a group that profoundly lacks environmental awareness.

Since 1989, there has been a push from both Romani activists and the Hungarian state, for example, to identify and organize Roma as an ethnic group and to target policies towards them. Strategically speaking, many activists and politicians fear that "ethnicizing" political issues of Roma communities marginalizes those issues and promotes stereotypes, but without targeted programs, there is little incentive for members of the majority group to consult or include minorities (Kovats, 2003; Vermeersch, 2007). New alliances between environmentalists and Roma civil rights activists need to form in order to address environmental justice concerns without shunting them into an "ethnic politics" ghetto. 
With Central and Eastern European countries' accession to the European Union and the election of the first Romani members of the European Parliament (MEPs) in 2004, European-level programs increasingly encourage targeting and inclusion of Roma constituencies as part of social cohesion policy. This may create a political opportunity for collaboration between environmentalists and Roma activists that could potentially produce new forms of environmental identity and reduce stereotypes of Roma as environmental profligates.

Racialization Processes and the Creation of Environments "Beyond the Pale"

Roma have experienced a long history of discrimination and persecution in Europe (Crowe, 1995; Hancock, 2002). Interethnic relationships between Roma and non-Roma in CEE have varied across time and space, and Ladányi and Szelényi observe a historical pattern of cyclical change in which periods of relative integration are followed by periods of increased hostility and segregation (2006). The interwar period and the postsocialist period, in their schema, were marked by downward mobility and increased spatial segregation of Roma communities in Hungary, Romania, and Bulgaria. It is in the context of these cycles that patterns of environmental exclusion have come into being.

More than fifty years later, poor Roma settlements throughout the region are located on the outskirts of villages, separated from the majority population by roads, railways or other barriers, and disconnected from water pipelines and sewage treatment. What role did environmental conditions play in the selection process? Is it an accident that Roma shantytowns are frequently located next to landfills, on contaminated land, or that they are regularly exposed to floods? Why do water pipelines end on the edges of their settlements, so that people have to walk miles every day just to collect potable water for cooking and drinking?

Roma settlements can be born out of or become problematic sites. In either case, land that is inhabited by the Roma can increasingly become a receptacle for environmental harms or a sphere within which environmental goods and services are denied. Non-Roma may construct these areas as devalued lands considered "beyond the pale." Settled areas, whether or not they are already environmentally degraded, are vulnerable to being designated sites for both formal and informal environmentally problematic projects and activities (e.g., the location of a new landfill or illegal waste dump) as well as being ignored 
when it comes to infrastructure developments or improvements (e.g., public water system and/or sewage treatment). Additionally, as new development plans are underway, one of the first stages may be to shift the Roma from centrally located (and increasingly valuable) areas to other places on the periphery where opportunities, resources, and services can be scarce.

The expression, "beyond the pale," historically referred to territories in Ireland where the English did not settle. English colonizers' civilization stopped at the boundary of the pale, and beyond the boundary of the pale, uncivilized and unruly segments of society could be found (Quinion, 2008). What might usually be considered unacceptable behavior in most places, could be tolerated in areas "beyond the pale." The term has come to mean territories that are not subject to the same rules or norms as much of the surrounding area. They are spaces characterized by what Valerie Kuletz terms "deterritoriality": "the loss of commitment by modern nation-states (and even the international community) to particular lands and regions" (Kuletz, 1998: 7). In the context of contemporary Europe, in which urban space is increasingly marked by class and ethnic hierarchies, poor Roma communities fall outside the "west" and the majority society despite the fact of their EU citizenship:

EU accession for the post-socialist countries has resulted in a de facto centre and periphery within Europe itself, thus exacerbating the already marginal economic and political position of Roma in Europe, whose communities continue to subsist as internal colonies within Europe. The multiple levels of colonization, for example, Western over eastern Europe, propels eastern Europeans to show their 'western credentials' by increasingly separating themselves from Roma, otherising them further, and thus fueling the racialised social pecking order (Trehan and Koczé n.d.: 27-8)

In the case of low-income Roma communities in Slovakia and Hungary, "beyond the pale" constructions of space may have multiple impacts on people and the environment. In addition to any pre-existing environmental threats, such racialized constructions invite additional or compounded environmental or health stresses and impacts. Standards or mitigating measures are more "flexible." Moreover, once constructed as a place "beyond the pale," a vicious cycle can ensue in which overall conditions decline at multiple levels.

While environmentally damaging activities, within the purview of settlements 
labeled "renegade," may be accepted (and legitimized) by non-Roma, resistance from "beyond the pale" faces multiple obstacles. Roma may generate certain pressures on the decision-making process (mostly if they are supported by external agents like NGOs), but their influence is very circumscribed. The division between spaces occupied by Roma and non-Roma may have a tendency to deepen. People living in the marginalized space will be further exposed to environmental threats and their access to environmental benefits may be further diminished. Communities may find themselves surrounded by waste from cities or exposed to the construction of problematic facilities. When Roma communities demand access to public infrastructure or improved environmental conditions, local authorities often respond only if there is specially targeted funding from a "Roma program," rather than making the politically unpopular move of allocating regular municipal funds toward a Roma neighborhood.

\section{ENVIRONMENTAL JUSTICE RESEARCH IN CEE: TWO CASE STUDIES}

Research and activism on environmental justice in CEE is relatively new. The environmental justice framework offers activists and policymakers the opportunity to bridge three of the most critical policy areas for CEE countries today: environmental protection, social cohesion, and health with a special focus on widespread and persistent discrimination against members of the Romani ethnic minority (Steger et al., 2007). Current research on environmental justice concerns within CEE countries is focused on site-specific case studies. Research, case studies in particular, demonstrate the role of discrimination in exposure to environmental harms on Roma settlements and in some cases, the subsequent health impacts (Filčák 2007; Harper 2006; Gille 2002; Steger et al. 2007). An overview of these indicates that the following issues merit special attention: exposure to environmental hazards including natural disasters such as risk of flooding, and lack of basic facilities including potable water, solid waste disposal, and sewerage.

\section{Case Study: Slovakia}

Filčák's research on environmental inequalities in eastern Slovakia uses rapid rural assessment survey data and in-depth case study research to uncover the dynamics of environmental inequalities in that region. Slovakia, one of the European Union's new 
member states, is a country facing many social, economic and environmental problems affiliated with rapid reforms of policies, global economic development and domestic pressures. Environmental pressures, a high poverty rate and growing regional disparities are among the most significant problems at the local level.

The region of the country where the transformation impacts and affiliated problems are most visible is eastern Slovakia, which is a rather diverse region. There are two popular national parks in the north (High Tatras Mountains and Slovak Paradise), an extensive eastSlovak basin in the southeast, and forest areas in the central part. Industrial production has been traditionally concentrated in the Middle-Spis region around the town Spišská Nová Ves, with a long record of mining, metal processing and industrial production dating back to medieval times.

Current conditions have roots in the land distribution decisions that came at the end of World War II. Czechoslovakia had been liberated and among the first laws adopted by the newly formed government was the "Directive on Governing Certain Conditions of Gypsies," where section 2 states: "In villages where they [Roma] have dwellings in proximity to public, state-owned and other roads, the dwellings will be removed, placed separately from the village on distant places selected by the village" (Jurova, 2002). This was neither the first nor the last attempt to regulate Roma settlements and separate them from villages of non-Roma. As newcomers to villages with practically no resources to buy land, Roma were allowed to settle only in places allocated to them by non-Roma decisionmakers.

After the Second World War, the mining, metal-processing and chemical industries were given priority in planning and investment. As a result, there are many environmental "hot spots" of old environmental liabilities in the region. The most important industrial and business centers today are Prešov (textile and timber), and Košice (iron mills, metal processing). Traditional agriculture, which is in decline, has been gradually replaced by the tourist industry as the fastest growing segment of the economy.

The region is among the poorest in the European Union. It belongs to Nomenclature des Unités Territoriales Statistiques (NUTS) II category according to the European Union 
classification and consists of two counties: Prešov and Košice. 2 These counties have the highest share of population dependent on social assistance (16.1\% and 18.9\% respectively) in Slovakia, with unemployment rates above 20\%. Average monthly income of a household member in Prešov County is the lowest in the country.3 In January 2004 the average registered unemployment rate in Slovakia was 16.6\%, in the capital Bratislava it was 3.7\% while in the Košice region it was 23.4\% (Slovak Ministry of Employment, Social Affairs and Family, 2008).

The latest data on the size and conditions of the Roma communities in Slovakia are from the 2004 survey carried out by a group of sociologists from the Social Policy Analysis Center (SPACE) Foundation and Institute for Public Affairs Bratislava with the support of the World Bank and Canadian International Development Agency. The survey, conducted for the office of the cabinet's plenipotentiary for Roma communities, indicates that 320,000 Roma live in Slovakia in 1,575 integrated and segregated settlements (Juraskova, et al., 2005). Most of them are located in eastern Slovakia, where there is also the highest concentration of segregated settlements.

Out of the identified 619 segregated Roma settlements in Slovakia, as many as 418 are located in the eastern part of the country. In this poor region Roma are the poorest of the poor. Social stratification is high, and a significant number of Roma live in the absolute poverty of rural shantytowns. There are Roma settlements in these areas with almost 100\% unemployment; people are unable to afford basic utilities (e. g., water, electricity or heating) or even food (UNDP, 2002; World Bank, 2003; Scheffel, 2005).

Filčák conducted field research (as the main source of qualitative data for this work) in the eastern part of the Slovak Republic in the period 2003-2005. The core of the fieldwork is in two case studies, involving five settlements. These are Pätoracké and Zabíjanec settlements in the case study of Rudňany, and communities in Hermanovce, Jarovnice and Svinia in the Upper Svinka Watershed case study. Selection of case studies

2 NUTS - Nomenclature des Unites Territoriales Statistiques or sub-national administrative areas within the European Community.

3 In the case of Košice, better macro-data are influenced by the performance of Košice as a regional hub and the second largest city in the country. 
was done based on the initial evidence of the inequalities in the distribution of environmental benefits and harm collected during the pilot study done prior to the main research. Both cases were identified to fulfill the characteristics of environmental injustice cases. In the case studies the history of environmental injustice, social processes, the role of stakeholders, and class and race effects on the distribution of environmental benefits and harm were studied. Outcomes of the case studies were analysed vis-à-vis a regional survey done on a random sample of 30 settlements. The contribution of this regional research was meant to be threefold. The first contribution was to provide a broader picture of the environmental and social conditions of Roma settlements in the area. The second contribution was to validate the selection of case studies and their relevance for analyses of a broader picture of environmental injustice. And last but not least, disclosure of other potential forms and impacts of environmental injustice not described in the case study research was sought. The regional research was conducted using Rapid Rural Appraisal methodology, which is built on qualitative research techniques.

Four main patterns of environmental injustice were identified in the research. Patterns of environmental injustice are defined here as specific, representative types of interactions between humans and the environment, where environmental benefits and/or harm are unequally distributed. They are used for the description of the interactions leading to environmental injustice and for analyses of the dynamics behind them. Construction of the patterns helps to understand the dynamics of the social processes contributing to their origin and serves for better analyses of opportunities offered by development policies (focusing especially on environmental management) to reduce vulnerability of the affected people to environmental injustice and improve their well-being.

The four patterns of the unequal distribution of environmental benefits and harm identified in the research are: 1) exposure to hazardous waste and chemicals (settlements at contaminated sites); 2) vulnerability to floods; 3) differentiated access to potable water; and 4) discriminatory waste management practices. While the four identified patterns of environmental injustice may not (and probably they do not) represent all potential forms of environmental injustice, they summarize patterns identified in the field research.

The patterns represent four specific types of unequal distribution of environmental benefits and harm. Although different in forms and scope, they possess several common 
features. They are the outcome of division in the villages, where through social processes the weaker group (Roma) is unequally exposed to adverse environmental impacts or has limited access to environmental benefits. The location of settlements, management of natural resources or waste is largely an outcome of conflicts over space in villages, and the environment plays an important role in the struggle. An interview with a 47-year-old Roma man from Pätoracké from the summer of 2004 illustrates some of these points:

PF: Gadjos [non-Roma] did not want us in the village, they told us to leave.

Filčák: Were you threatened to leave?

PF: They said we should leave, so we did. I don't remember exactly, I was kid in those times. Somebody told us there were rooms empty [in the former administrative building]. It was also closer to my father's work.

Filčák: Were you aware that this place may sink down and that there is dirty land around?

PF: We were happy to have a place to stay. I want to move to these new houses but the mayor doesn't want to build more of them for us.

Case studies outcomes analyzed vis-a-vis broader regional survey provide data for identifying patterns of society-nature relations and unequal exposure to environmental harms (or access to environmental goods respectively). This helps us to explain dynamics of environmental marginalization. Filčák identifies three main factors influencing decisions of the majority towards the selection of environmentally problematic places for Roma settlements. These are:

- Economic interests (the price of the land/real estate value, commercial potential);

- Ethnic discrimination and spatial distance (proximity to the main village and racial prejudices/the effort to push Roma out of the main village), and

- Competition over resources (entitlements, management of the resources and access to employment).

Economic interests are a very powerful driving force behind decision making, but ethnic discrimination also plays an important role. Non-Roma do not want Roma in the main village and are often able (as illustrated in the case of Rudňany) to find ways to push them to the outskirts. Environmental conditions may (mainly through their impact on the 
value and commercial potential of the land) play a decisive role in the selection of places for settlements. As Anna Husarova from Jarovnice points out in her account on how the Jarovnice shantytown was built:

[After the war] survivors had to settle next to forests, in the middle of fields or on riverbanks. These were the only places where they were allowed to settle down and start over. They built huts and began to call them flats. No attention was paid to them, and they were given no help. (Horackova 2000)

Environmental discrimination does not stop with the selection of places. Once the places for the settlements are selected and inhabited by Roma, they may become places for other environmentally unfriendly activities. The municipality in Rudnany regularly collected waste from the non-Roma part of the village and illegally deposited it near the Roma shantytown in Patoracke. A commercial landfill for supermarkets was built in 2005 in the Roma part of the village of Svinia. These and other cases indicate that parts of villages inhabited by Roma are considered to be "lost" for any meaningful investment, and the local council is well aware of the fact that Roma, as the least powerful group on the local level, will not generate sufficient pressure to prevent this type of land use. The space is then constructed as "beyond the pale." It means conceptualization of Roma village sections as "beyond the pale" spaces where environmentally controversial practices are (or may be) gradually concentrated.

\section{Case Study: Northeastern Hungary}

In spring 2007, Harper conducted a participatory action research (PAR) project with members of the Sajó River Association for Environment and Community Development (Sajómenti Környezet- és Közösségfejlesztök Egyesülete, or SAKKF) in Sajószentpéter, Hungary. SAKKF is a grassroots community organization located in a predominantly Roma neighborhood near the Sajó River wetlands in Sajószentpéter, Hungary. Participatory action research is a methodology in which members of a community or organization take an active role in studying problems alongside a traditional researcher in order to develop strategies for change. Yvonne Wadsworth writes: "participatory action research is not just research which we hope will be followed by action! It is action which is researched, changed and reresearched, within the research process by participants" (Wadsworth, 1998). In 
Sajószentpéter, the collaborative project harnessed the power of visual images and critical discussion to examine positive and negative aspects of the community's environment, using PhotoVoice research methods. Through mutual engagement in research and action, the PAR team sought to assess and improve environmental and public health conditions for the community, to gain access to environmental decision-making, and to organize individual and collective actions toward a more livable, just, and sustainable future.

Harper and Jutka Bari, the president of SAKKF, developed a research plan involving young people from the community as researchers. They were attracted to the PhotoVoice research method because of its potential to attract the interest of young people and to rapidly generate visual data on environment and health issues. Developed by public health scholars Carolyn Wang and Mary Ann Burris, PhotoVoice is a PAR method in which a group of community members uses cameras to take photos on a theme (Wang and Burris, 1997). The photos are then selected by photographers themselves and used in group discussion to elicit comments. PhotoVoice research is aimed not only at raising awareness in a community but also at communicating with policymakers and representatives of institutions that are often inaccessible for members of disadvantaged groups. Throughout the PhotoVoice research process, participants discuss their ethical relationship with their photographic subjects, changes they would like to see in their lives, and strategies for collective action to address problems depicted in the photos.

Sajószentpéter (pop. 14,000) was a minor industrial center near Miskolc in northern Hungary for most of the twentieth century, producing glass and coal until the factory and mine were privatized and closed down following the collapse of state socialism in the early 1990s. The entire population of the town lost its livelihood in the space of a few months, and no new employers have appeared in the subsequent decade and a half. Surrounded by fields and the Sajó River wetlands, the predominantly Roma neighborhood where SAKKF is based is at least 100 years old and has over 2000 residents, most of them Roma. Connected to the rest of town by a bridge, the community is a two-minute walk to the main square where the mayor's office is located.

Harper and Bari first met in 2005, discovered their common interest in understanding connections between Roma communities and the environment, and decided to work together on these themes. The founding members of SAKKF had included 
"environment" in the organization's name five years earlier, with the hope of involving community members in the restoration of fishing holes in the nearby wetlands. The group set aside these initial plans to focus on youth, community development, and public health for its first projects. Nevertheless, several members of the organization remained interested in the theme and agreed to participate in collaborative research on environmental issues.

In spring 2007, six young community-based researchers (ages 18-24) participated in training sessions on photography and research ethics, leading to a discussion of critical themes: the politics of representation of Roma as a minority group, the young researchers' relationship to the rest of the community, and what it means to be on either side of the camera's lens. At the second official meeting of the research team, Harper distributed small digital cameras to the photographers. Harper and Bari presented the first theme, "environment," and asked participants to define the term broadly and to include both positive and negative aspects of environmental conditions and people's beliefs and practices related to the environment.

By the following week, the photographers had taken over 400 photos related to the environment. Quickly running through the photos, the team noticed that almost half showed trash heaps and dumping sites in and near the neighborhood. Clearly, waste management and the problem of illegal dumps would be an important focus. Other environmental problems appeared in fewer photos, but in discussion emerged as key concerns for the community organization. Once the group had selected a manageable number of photos for group discussion, they quickly arranged them as a digital slideshow and gathered around a laptop computer to discuss the images. Even though everyone was aware that photos capture and condense information, team members were all amazed to discover how each picture opened up stories, emotions, and new questions.

Photographs drew attention to the following environmental problems and injustices experienced in the neighborhood:

- unequal access to sewerage or wastewater treatment

- unequal access to household water

- unequal access to green space and playgrounds

- waste management and illegal dumping by outsiders as well as residents

- energy; including household energy efficiency and access to fuel for heating and 
cooking

- poor housing quality, which relates back to energy efficiency, access to public infrastructure, and human health

- lack of access to telecommunications infrastructure and information technologies that are available in other parts of town

Photos also drew attention to positive aspects of environment and health the community, most of which had rarely been recognized by residents or outsiders. These include:

- sense of connection to surrounding wetlands through fishing and recreation along river banks

- use of environmentally friendly transportation such as bicycles, public transportation, horses, carpools, and walking

- attachment to place expressed through gardening and animal husbandry

- participatory sports such as football as a source of community pride and personal health

During group discussions, the photographers not only voiced the hidden stories behind images, they also talked about what the organization could do to seek remedy for environmental inequalities and to recognize and promote existing strengths and environmentally friendly practices. Over several months, the photographers used their cameras to document a wider set of community issues.

In June 2007 the group presented its work at photo exhibitions in Sajószentpéter and Budapest. The team decided to hold the local exhibition on the street at the entrance to the neighborhood. Although this venue posed logistical challenges, the young photographers wanted to ensure that everyone from the community could to see the exhibition. As an added benefit of holding the exhibition in the neighborhood, the organization would be able to see which policymakers and potential partners were willing to cross the bridge to attend an event on the cigánysor ("Gypsy row"). Inspired by their choice of venue, the photographers decided to give the local exhibition the title, "This is also Sajószentpéter" ("Ez is Sajószentpéter"). The photographers posted flyers around the town and invited the mayor and vice mayor, local council members, key public administrators, representatives of the Gypsy self-government, and doctors, nurses and teachers serving the neighborhood. The 
group also invited potential partners from environmental and civil rights organizations working at the regional, national, and international levels, and the county's main newspaper published a front-page story about the exhibition. The photographers took the opportunity to share their work with the rest of the community and receive valuable feedback, to extend the organization's network of partners and supporters, and to open a broader discussion of environment and health issues in the neighborhood. Nevertheless, several important policymakers, including the mayor and vice-mayor, did not attend although they tasked a member of the town council with sending their respects. The group would like to use the photos to hold a series of facilitated discussions with community members and policymakers, with the goal of developing policy responses to the issues raised.

The team held the Budapest exhibition at the Central European University, hosted by the Center for Environmental Policy and Law. For several members of the research team, it was the first time they had visited the capital city, less than three hours' travel from Sajószentpéter. The event included a 90-minute group discussion in English and Hungarian of the issues raised by the photos, facilitated by a nationally-known Roma civil rights activist and a respected environmental lawyer. In addition to providing a broader audience for the photographers' work, the exhibition allowed SAKKF members to extend their social network beyond Sajószentpéter. Following the exhibitions, the organization received visitors from a human rights organization and made partnerships with non-Roma organizations that led to the submission of grant applications addressing public participation in environmental planning. However, at a time when many of the most active residents of the neighborhood travel long distances to make a livelihood, SAKKF's capacity for action has been limited.

\section{CONCLUSIONS}

The struggle for environmental justice within and across global spheres (e.g., North and South, West and East) widely expanded the discourse and aims of contemporary environmentalism. Our work actively participates in this shift and contributes to its further development by not only participating in the methodological debate, but also theorizing and sharing empirical studies in the context of CEE. The historical and political circumstances in CEE described here and the cases analyzed in this article demonstrate social processes 
that create the conditions for and contribute to the unequal distribution of environmental benefits and harm in "beyond the pale" environments.

Furthermore, the methodological approaches applied the two case studies demonstrate the benefits of varied and participatory approaches. Understanding not only the historical and political evolution of CEE, but also the local context and capacities of the social actors is particularly crucial for establishing a regionally appropriate vocabulary for effective environmental justice mobilizations and policy formation.

The situation in Eastern Slovakia indicates a lack of political mobilization or selforganizing structures in Roma shantytowns, which limits communities' capacities to formulate their own agendas and to intervene from the "bottom up" in decision-making processes. Hence, the outcome of competition and conflict over access to and management of natural resources between the two considered social groups (Roma and non-Roma) with unequal social and political status can inevitably lead to the dominance of non-Roma local elites. Race and class also play significant roles in access struggles and residential segregation and marginalization. As Pellow (2001) posits, those stakeholders who are unable to mobilize resources (political, economic, etc.) will most likely bear the brunt of environmental inequalities. The results of this competition and the "resolution" of the conflict are manifested in the siting of Roma settlements as well as the conceptualization of Roma village sections as "beyond the pale" spaces where environmentally controversial practices are (or may be) gradually concentrated. In the case of Slovakia, the disadvantaged position of the Roma, furthermore, prevents their communities from better protection against unequal treatment.

In Hungary, we observe environmental inequalities between Roma and non-Roma neighborhoods in the same town - a pattern borne out in cities across the country (Debrecen School of Public Health, 2004). Unequal access to sewerage, indoor water, sanitation, and green space are common issues affecting neighborhoods designated the cigánysor ("Gypsy Row"). Prospects for environmental justice mobilizations and the development of environmental identities appear more promising in that early instances of Roma community organizing involved access to housing and public infrastructure. In the case of SAKKF, members of the group actively chose the integrative language of environment and community development over designating themselves as an ethnic organization, despite 
members' acute awareness of discrimination and racism. Residents' claims for their rights as citizens to a clean environment are compromised by municipal authorities' perception of low-income Roma as dependents, however, and by the more general difficulty for lowincome people in the provinces to sustain grassroots civil organizations once they have been established.

Environmental justice reflects a growing wave of environmentalism as people seek justice in the distribution of environmental benefits and harms. Fundamental to this process is not only the application of distributive and procedural notions of justice, but a widening discourse on what constitutes an environmentalist and environmentalism. Further research on environmental justice in CEE will need to explore the opportunities and barriers to an emergent environmental identity amongst the Roma, and their capacity to generate "new vocabulary" around that identity.

The status of Roma minority communities in society and the quality of the environmental conditions under which they reside and work is an indicator of how successful European society is at recognizing and integrating marginalized communities and people. The status or treatment of Roma and environmental protection have a direct relationship, as in circumstances referred to as "beyond the pale." Further, as Mohai pointed out, broadening racial and ethnic minority groups' participation in ecological activities can play an important role in transforming ecological attitudes and promoting social inclusion (Mohai, 1990). Environmental justice studies involving the Roma will provide a basis for longer term broader research on the distribution of environmental benefits and in the Central and Eastern Europe. Moreover, they offer a window of opportunity for a better Europe through simultaneous strengthening of social cohesion, poverty reduction, and environmental protection.

\section{ACKNOWLEDGEMENTS}

Krista Harper's field research was supported by a Fulbright European Union Affairs Research Fellowship and by a Faculty Research Grant from the University of Massachusetts Amherst. The Central European University's Department of Environmental Sciences and Policy provided institutional support throughout our research collaboration. We thank Alex Antypas, Roberta Garner, Zsuzsa Gille, and two anonymous reviewers for comments on earlier versions of this paper. 


\section{REFERENCES}

Agrawal, Arun. 2005. Environmentality: Technologies of Government and the Making of Subjects. Durham, NC: Duke.

Agyeman, Julian. 2002. Constructing environmental injustice: transatlantic tales. Environmental Politics 3: 31-53.

Antypas, Alexios, Claude Cahn, Richard Filčák, and Tamara Steger. 2008. "Constructing Environmental Protection, Health, and Human Rights in the European Union.” Environmental Law and Management 20: 8-21.

Ash, Michael, and T. Robert Fetter. 2004. Who Lives on the Wrong Side of the Environmental Tracks? Evidence from the EPA's Risk Screening Environmental Indicators Model. Social Science Quarterly 85(2): pp. $441-462$.

Autonómia Foundation/UNDP. 2004. "Energiatakarékossági kísérleti programok az Encsi kistérségben" ("Household energy pilot project for Roma settlements in Encs region"). Budapest, Autonomia Foundation.

Baden, Brett M., Douglas S. Noonan, and Rama Mohana R. Turaga. 2007. Scales of Justice: Is there a Geographic Bias in Environmental Equity Analysis? Journal of Environmental Planning and Management. 50 (2):163-185.

Barnes, P. and Barnes, I. 1999. Environmental policy in the European Union. Cheltenham, UK: Edward Elgar.

Bowen, William M. and Kingsley Haynes. 2000. The Debate over Environmental Justice. Social Science Quarterly 81:3.

Bowen, W. M., and Wells, M. V. 2002. The politics and reality of environmental justice: a history and considerations for public administrators and policy makers. Public Administration Review 6 (62): 688-698.

Briggs, C. M. 2006. Science, local knowledge and exclusionary practices: Lessons from the Alta 
Dam Case. Norwegian Journal of Geography. 60:149-160.

Brosius, J. Peter. 1997. Endangered Forest, Endangered People: Environmentalist Representations of Indigenous Knowledge. Human Ecology 25(1): 47-69.

Checker, Melissa. 2001. "Like Nixon Coming to China": Finding Common Ground in a MultiEthnic Coalition for Environmental Justice. Anthropological Quarterly 74(3): 135-46.

Cole, L.W., and Foster, S.R. 2000. From the ground up: environmental racism and the rise of the environmental justice movement. New York: New York University Press.

Crowe, David. 1995. A History of the Gypsies of Eastern Europe and Russia. New York: Palgrave MacMillan.

Csalog, Zsolt. 1994. Gypsies in the Hungarian Labor Market. Szociológiai Szemle 1994(2): 75-

78. Accessed online at http://www.mtapti.hu/mszt/19942/csalog.htm (July 10, 2008).

Debrecen University School of Public Health. 2004. “Telepek és Telepszerü Lakóhelyek

Felmérése." ("Survey of Settlements and Settlement-type Residences”). Debrecen, Hungary:

Debrecen University School of Public Health.

De la Pena, N. and S. Davis. 1990. The greens are white. Newsweek 116: 16.

Delemos, Jamie. 2006. Community-Based Participatory Research: Changing Scientific Practice from Research on Communities to Research with and for Communities. Local Environment. 11(3): 329338.

Downey, Liam. 2007. US Metropolitan-area Variation in Environmental Inequality Outcomes. Urban Studies 44(5/6):953-977.

Emigh, R.J. 2001. The racialization and feminization of poverty? In Poverty, ethnicity, and gender in Eastern Europe during the market transition, R. J. Emigh and I. Szelényi (eds.), pp. 1-33. Westport, CT.: Praeger. 
Economic and Social Research Council (ESRC). 2001. Environmental Justice: Rights and Means to a Healthy Environment for All. Special Briefing No. 7. ESRC Global Environmental Change Program.

Filčák, R. 2007. Environmental justice in the Slovak Republic: the case of Roma ethnic minority. PhD Dissertation, Department of Environmental Sciences and Policy, Central European University, Budapest.

Friends of the Earth (FoE). 2001. Pollution and poverty - breaking the link. London: Friends of the Earth.

Gille, Zsuzsa. 2002. Social and Spatial Inequalities in Hungarian Environmental Politics: A Historical Perspective. In Livable Cities? Urban Struggles for Livelihood and Sustainability, Peters Evans (ed.). Berkeley: California.

Gouldson, Andy. 2006. Do firms adopt lower standards in poorer areas? Corporate social responsibility and environmental justice in the EU and the US. Area. 38 (4): 402-412.

Grineski, Sara E. 2006. Local Struggles for Environmental Justice: Activating Knowledge for Change. Journal of Poverty. 10(3): 25-49

Hancock, Ian. 2002. We are the Romani People. Hertsfordshire, UK: Hertsfordshire.

Harper, Krista. 2005. "Wild Capitalism" and "Eco-colonialism": A Tale of Two Rivers. American Anthropologist 107 (2): 221-233.

-----2006. Wild Capitalism: Environmental Activists And Post-Socialist Ecology in Hungary. Boulder, CO: East European Monographs.

Harper, K., and Rajan, S. 2007. International environmental justice: building natural assets for the poor. In Reclaiming Nature: Environmental Justice and Ecological Restoration, James Boyce, Sunita Narain, and Elizabeth Stanton (eds... Chicago: Anthem.

Heinz, Teresa L.. 2005. From Civil Rights to Environmental Rights: Constructions of Race, 
Community, and Identity in Three African American Newspapers' Coverage of the Environmental Justice Movement. Journal of Communication Inquiry 29:1:47-65.

Horackova, Emilie. 2000. Survivors Had to Settle on River Banks (oral history interview with Anna Husarova, Jarovnice, Slovakia), http://stories-exchange.org/stories-and-responses/theholocaust/survivors-had-to-settle-on-river-banks/ (accessed on May 28, 2009).

Inglehart, Ronald. 1977. The silent revolution : changing values and political styles among Western publics. Princeton, NJ: Princeton.

Jurova, A. 2002. Rómovia vobdobí od roku 1945 po november 1989 [Roma in the time period 1945 until November 1989]. In Čačipen Pal o Roma: a Global report on Roma in Slovakia, M. Vašečka, et al. (eds.), pp. 53 - 77. Bratislava: IVO.

Kingham, Simon, Jamie Pearce, and Peyman Zawar-Reza. 2007. Driven to Injustice? Environmental Justice and vehicle pollution in Christchurch, New Zealand. Transportation Research. Part D. 12(4):254-263.

Krech, Shepard. 1999. The Ecological Indian: Myth and History. New York: W.W. Norton.

Kovats, M. (2003) The politics of Roma identity: between nationalism and destitution, OpenDemocracy.Net, see http://www.opendemocracy.net/people-migrationeurope/article_1399.jsp (July 11, 2008).

Kuletz, Valerie. 1998. The Tainted Desert. New York: Routledge.

Ladányi, János. 1991. A miskolci gettougy ("The Miskolc Ghetto Case"). Valóság 34 (4): pp. 4554.

Ladányi, János, and Iván Szelenyi. 2005. Patterns of Exclusion: Constructing Gypsy Ethnicity and the Making of an Underclass in Transitional Societies of Europe. Boulder, CO: East European Monographs.

Lemon, Alaina. 2000. Between Two Fires: Gypsy Performance and Romani Memory from Pushkin 
to Postsocialism. Durham, NC: Duke.

Li, Tanya. 2004. Environment, Indigeneity and Transnationalism. In eds. Richard Peet and Michael Watts, Liberation Ecologies, London: Routledge: pp. 339-370.

Martínez-Alier, Juan. 2003. The Environmentalism of the Poor: A Study of Ecological Conflicts and Valuation. Northampton, MA: Edward Elgar.

McCormick, J. 2001. Environmental Policy in the European Union. London: Palgrave Macmillan.

Mertig, Angela and Riley Dunlap. 2001. Environmentalism, New Social Movements, and the New Class: A Cross-National Investigation. Rural Sociology, 66(1):113-136.

Mohai, Paul. 1990. Black Environmentalism. Social Science Quarterly. 71(4): 744-765.

Norgaard, Kari Mari. 2007. The Politics of Invasive Weed Management: Gender, Race, and Risk Perception in Rural California. Rural Sociology 72:3:450-477.

Pastor, Manuel; Sadd, Jim; Morello-Frosch, Rachel. 2005. The Air is Always Cleaner on the Other Side: Race, Space, and Air Toxics Exposures in California. Journal of Urban Affairs 27(2).

Pellow, D. 2001. Environmental justice and the political process: movements, corporations and the state. Sociological Quarterly 42 (1): 46-6.

Pellow, David Naguib, Tamara Steger, and Rebecca McLain. 2005. Proceedings from the Transatlantic Initiative to Promote Environmental Justice Workshop, Central European University, Budapest, Hungary, October 27-30, 2005. Accessed online at http://calcultures.ucsd.edu/transatlantic_initiative/

Pickvance, Katy. 1998. Democracy and Environmental Movements in Eastern Europe. Boulder, CO: Westview.

Pulido, Laura. 1996. Environmentalism and Economic Justice: Two Chicano Struggles in the Southwest. Tuscon: Arizona. 
Ragin, Charles. 2000. Fuzzy-Set Social Science. Chicago and London: The University of Chicago Press.

Raina, Vinod. 2000. Why people oppose dams: environment and culture in subsistence economies. Inter-Asia Cultural Studies 1(1).

Robinson, E. E. 2002. Community frame analysis in Love Canal: understanding messages in a contaminated community. Sociological Spectrum 22: 139-169.

Sajó River Association for Environment and Community Development (SAKKF). 2007. Declaration of the Sajó River PhotoVoice Group. Sajoszentpeter, Hungary.

Scheffel, D. 2005. Svinia in Black and White: Slovak Roma and their Neighbours. Toronto: Toronto.

Schlosberg, David. 2004. Reconceiving Environmental Justice: Global Movements and Political Theories. Environmental Politics. 13:3:517-540.

Slovak Ministry of Employment, Social Affairs and Family website (www.employment.gov.sk) [Consulted 21 January 2005].

Steger, Tamara and Richard Filčák. 2008. Articulating the Basis for Promoting Environmental Justice in Central and Eastern Europe. Environmental Justice 1:1.

Steger, Tamara. 2008. The Role of Culture and Nationalism in Latvian Environmentalism and the Implications for Environmental Justice. In eds. Julian Agyeman and Yelena Ogneva-Himmelberger, Environmental Justice and Sustainability in the Former Soviet Union. Cambridge, MA: MIT.

Steger, Tamara, ed. 2007. Making the case for environmental justice in Central and Eastern Europe. Budapest Hungary: Health and Environment Alliance (HEAL), the Central European University, Environmental Justice Program, and the Coalition for Environmental Justice.

Sundberg, Juanita. 2008. Tracing Race: Mapping Environmental Formations in Environmental 
Justice Research in Latin America. In ed. David J. Carruthers, Environmental Justice in Latin America: Problems, Promise, and Practices. Cambridge, MA: MIT, 25-48.

Taylor, Dorceta. 2000. The Rise of the Environmental Justice Paradigm. American Behavioral Scientist 43(4): pp. 508-80.

Tickle, A., and Welsh, I. 1998. Environment and society in Eastern Europe. Essex, U.K.: Addison Wesley Longman.

Trehan, Nidhi, and Angéla Kóczé. N.d. "Racism, (neo)colonialism, and social justice: the struggle for the soul of the Romani movement in post-socialist Europe," unpublished manuscript.

United Church of Christ Commission for Racial Justice. 1987. Toxic Wastes and Race in the United States. Chavis Jr. Benjamin F. and Charles Lee. NY: United Church of Christ.

United Nations Development Programme (UNDP). 2002. The Roma in Central and Eastern Europe - avoiding the dependency trap, a regional human development report. Bratislava: United Nations Development Programme.

Vermeersch, Peter. 2006. The Romani Movement: Minority Politics And Ethnic Mobilization in Contemporary Central Europe. London: Berghahn.

Wadsworth, Yolanda (1998) What is Participatory Action Research? Action Research International, Paper 2. Accessed online at http://www.scu.edu.au/schools/gcm/ar/ari/p-ywadsworth98.html

Wang, Caroline C., and Mary Ann Burris. 1997. Photovoice: Concept, Methodology, and Use for Participatory Needs Assessment. Health Education and Behavior, 24(3): 369-387.

World Bank. 2000. Health needs of Roma population in the Czech and Slovak Republics (Literature review): Final report. Washington D.C.: World Bank.

---- 2003. Roma in expanding Europe - breaking the poverty gap. Washington D.C.: World Bank. 